\title{
Apparent digestibility coefficients of the extruded pellet diets containing various fish meals for olive flounder, Paralichthys olivaceus
}

\author{
Md Mostafizur Rahman ${ }^{1}$, Hyon-Sob Han², Kang-Woong Kim², Kyoung-Duck Kim², Bong-Joo Lee²
} and Sang-Min Lee ${ }^{1 *}$

\begin{abstract}
Apparent digestibility coefficients (ADCs) of dry matter, crude protein, crude lipid, energy, essential amino acids, and fatty acids in extruded pellets containing various fish meals were determined for olive flounder (Paralichthys olivaceus). Eight extruded pellet diets were prepared to contain different fish meals (herring fish meal, anchovy fish meal, mackerel fish meal, sardine fish meal-A, sardine fish meal-B, tuna fish meal, pollock fish meal-A, and pollock fish meal-B) designated as HM, AM, MM, SM-A, SM-B, TM, PM-A, and PM-B, respectively. Chromic oxide $\left(\mathrm{Cr}_{2} \mathrm{O}_{3}\right)$ was used as an inert indicator at a concentration of $0.5 \%$ in the diet. Feces were collected from triplicate groups of fish $(151 \pm 4.0 \mathrm{~g})$ using a fecal collection column attached to the fish rearing tank for 4 weeks. Dry matter ADCs of the MM, SM-A, SM-B, and PM-A diets were higher than those of all the other dietary groups, and the lowest digestibility of dry matter was observed in the PM-B diet. Fish fed the MM, SM-A, and PM-A diets showed significantly higher ADC of protein than those fed the $A M, S M-B, T M$, and PM-B diets. Lipid ADC of PM-B was significantly lower than that of the other diets. Energy ADCs of fish fed the MM, SM-A, and PM-A diets were significantly higher than those of the other diets. The availability of essential amino acids in the MM, SM-A, and PM-A diets were generally higher than that of the other fish meal diets, while TM showed the lowest values among all the experimental diets. ADCs of fatty acids in the AM, MM, SM-A, and PM-A diets were generally higher than those of fatty acids in the other diets, and the lowest values were recorded for the PM-B diet. These results provide information on the bioavailability of nutrients and energy in various fish meals which can be used to properly formulate practical extruded feeds for olive flounder.
\end{abstract}

Keywords: Paralichthys olivaceus, Apparent digestibility coefficient, Fish meals

\section{Background}

Determination of the digestibility of nutrients in diets provides the first indication of their nutritional value and is considered as the first step of their quality evaluation (Allan et al. 2000; Glencross et al. 2007; Luo et al. 2009; Liu et al. 2009). Fish meal is certainly the best dietary protein source because it is quite palatable and provides an excellent balance of essential amino acids and fatty acids and

\footnotetext{
*Correspondence: smlee@gwnu.ac.kr

'Department of Marine Biotechnology, Gangneung-Wonju National

University, Gangneung 25457, South Korea

Full list of author information is available at the end of the article
}

some other substances (Hardy 2010). Fish meal is the preferred animal protein supplement in the diets of aquatic animals. It carries huge quantities of energy and is rich in protein, lipids, minerals, and vitamins. It also serves as the benchmark ingredient in aquaculture diets because of its high nutrient content and digestibility (Udo et al. 2012). Fish meal in animal diets increases feed consumption, feed efficiency, and growth through better feed palatability and also improves nutrient uptake, digestion, and absorption among other ingredients (Yisa et al. 2013). Some studies have investigated apparent digestibility coefficients of various fish meals in several fish species such as grower 
rockfish, Sebastes schlegeli (Lee 2002); juvenile snakehead, Ophiocephalus argus (Yu et al. 2013); juvenile cobia, Rachycentron canadum (Zhou et al. 2004); Nile tilapia, Oreochromis niloticus (Köprücü and Özdemir 2005); Atlantic cod, Gadus morhua (Tibbetts et al. 2006); and juvenile haddock, Melanogrammus aeglefinus L. (Tibbetts et al. 2004). The raw materials of fish meal are processed by heating, pressing, separation, evaporation, and drying. Heating condenses the protein, breaks the fat depots, and also releases oil and water. Pressing improves the meal quality and decreases the moisture content of the press cake as much as possible. Drying process removes sufficient water from the wet and unstable mixture of press cake to form a stable fish meal.

Extrusion process can cause physical and chemical changes, such as ingredient particle size reduction and inactivation of enzymes. In addition, the heat associated with the extrusion process may also cause deactivation of anti-nutritional factors (Allan and Booth 2004) and improve the utilization of nitrogen-free extracts or other elements (Burel et al. 2000). Extrusion may also confer important benefits to the physical attributes of pellets including nutrient digestibility, palatability, pellet durability, water stability, and pellet storage life (Barrows and Hardy 2000). Extruded pellets are highly recommended for fish culture because of easy observation of feeding activity, easy management, and minimal water pollution. Cho et al. (2006) reported that extruded pellets can improve the digestibility of ingredients and they are generally well accepted by olive flounder, Paralichthys olivaceus.

Olive flounder is a commercially important carnivorous fish widely cultured in Eastern Asia including Korea, Japan, and China (Kim et al. 2014). Previous studies were conducted to investigate apparent digestibility coefficients of various fish meals for flounder (Deng et al. 2010; Kim et al. 2010). However, only limited information is available on the digestibility of different fish meals in flounder-extruded pellets. Therefore, the present study was conducted to determine the apparent digestibility coefficients of dry matter, crude protein, crude lipid, energy, essential amino acids, and selected fatty acids from different fish meals used in extruded diets for olive flounder.

\section{Methods}

\section{Diet preparation}

The proximate, essential amino acid and fatty acid (\% of total fatty acids) compositions of the test ingredients (fish meals) are shown in Tables 1 and 2, respectively. Eight experimental diets were formulated using steam-dried herring fish meal, anchovy fish meal, mackerel fish meal, sardine fish meal-A, sardine fish meal-B, tuna fish meal, pollock fish meal-A, and pollock fish meal-B (designated as HM, AM, MM, SM-A, SM-B, TM, PM-A, and PM-B, respectively) (Table 3). Chromic oxide $\left(\mathrm{Cr}_{2} \mathrm{O}_{3}\right)$ served as the inert indicator at a concentration of $0.5 \%$ in the diet. All dry ingredients were thoroughly mixed, and the experimental diets were manufactured using a twin-screw extruder (Model ATX-2, Fesco Precision Co., Daegu, Korea). Extrusion conditions were as follows: feeder speed, 16 to $18 \mathrm{rpm}$; conditioner temperature, $75^{\circ} \mathrm{C}$; main screw speed, $640 \mathrm{rpm}$; and barrel temperature, 100 to $115{ }^{\circ} \mathrm{C}$. Extruder pellets were oven-dried at $60^{\circ} \mathrm{C}$ for $6 \mathrm{~h}$ to maintain the moderate moisture content of 5 to $8 \%$ and stored at $-25^{\circ} \mathrm{C}$ until use.

\section{Fish and experimental condition}

Juvenile olive flounder were obtained from a hatchery (Namhae, Korea) and acclimated to the laboratory conditions for 10 months. The experimental fish (151 \pm $4.0 \mathrm{~g})$ were then randomly distributed into 400-1 cylindrical fiberglass tanks filled with $200 \mathrm{l}$ of water at a density of 25 fish per tank. Filtered seawater was supplied at a flow rate of $3 \mathrm{l} / \mathrm{min}$ to each rearing tank. Fish rearing tanks had a sloping bottom leading to a centrally located drainage slot, and the effluent water was first directed over a fecal collection column before going to waste (Lee 2002). The water temperature was

Table 1 Proximate and amino acid compositions of the fish meals used to test diets

\begin{tabular}{|c|c|c|c|c|c|c|c|c|}
\hline & \multicolumn{8}{|c|}{ Fish meals } \\
\hline & $\mathrm{HM}$ & AM & MM & SM-A & SM-B & TM & PM-A & PM-B \\
\hline \multicolumn{9}{|l|}{$\begin{array}{l}\text { Proximate analysis } \\
\text { (\% in dry matter) }\end{array}$} \\
\hline Dry matter & 93.3 & 92.2 & 92.4 & 91.3 & 94.0 & 92.0 & 93.7 & 93.1 \\
\hline Crude protein & 73.4 & 67.3 & 76.6 & 71.5 & 71.0 & 62.7 & 74.7 & 63.3 \\
\hline Crude lipid & 10.4 & 8.6 & 6.8 & 10.0 & 10.2 & 10.6 & 5.9 & 5.4 \\
\hline Ash & 16.6 & 19.7 & 16.7 & 16.0 & 14.6 & 20.1 & 15.7 & 26.4 \\
\hline $\begin{array}{l}\text { Gross energy } \\
(\mathrm{kcal} / \mathrm{g})\end{array}$ & 4.9 & 4.5 & 4.6 & 4.7 & 4.8 & 4.3 & 4.7 & 3.9 \\
\hline \multicolumn{9}{|c|}{$\begin{array}{l}\text { Essential amino acids } \\
\text { (\% in protein) }\end{array}$} \\
\hline Arg & 6.4 & 6.0 & 6.5 & 7.1 & 6.4 & 6.4 & 7.1 & 7.0 \\
\hline His & 2.8 & 2.0 & 4.5 & 2.5 & 3.0 & 3.3 & 2.5 & 2.5 \\
\hline lle & 4.4 & 4.0 & 4.5 & 4.1 & 4.7 & 4.2 & 3.9 & 4.2 \\
\hline Leu & 8.0 & 6.6 & 7.9 & 7.8 & 8.3 & 7.6 & 8.0 & 8.0 \\
\hline Lys & 8.4 & 7.2 & 8.6 & 5.8 & 8.9 & 9.3 & 5.7 & 5.3 \\
\hline Met + Cys & 4.2 & 3.9 & 4.3 & 2.7 & 4.3 & 4.0 & 2.8 & 2.9 \\
\hline Phe + Tyr & 7.6 & 6.3 & 7.5 & 8.0 & 8.0 & 7.2 & 8.3 & 8.3 \\
\hline Thr & 4.8 & 4.8 & 4.7 & 4.2 & 4.9 & 4.8 & 4.9 & 4.3 \\
\hline Val & 5.9 & 4.9 & 5.0 & 4.4 & 5.3 & 5.6 & 4.3 & 4.7 \\
\hline
\end{tabular}

$H M$ herring fish meal, $A M$ anchovy fish meal, $M M$ mackerel fish meal, $S M-A$ sardine fish meal-A, $S M-B$ sardine fish meal-B, $T M$ tuna meal, $P M-A$ pollock fish meal-A, $P M-B$ pollock fish meal-B 
Table 2 Fatty acid compositions (\% of fatty acids) of the fish meals

\begin{tabular}{|c|c|c|c|c|c|c|c|c|}
\hline & Fish $n$ & neals & & & & & & \\
\hline & $\mathrm{HM}$ & AM & MM & SM-A & SM-B & TM & PM-A & PM-B \\
\hline C14:0 & 4.6 & 4.2 & 3.6 & 4.7 & 5.4 & 3.8 & 2.2 & 3.3 \\
\hline C14:1 & 0.4 & 0.3 & 0.6 & 0.6 & 0.5 & 1.0 & & 0.4 \\
\hline C16:0 & 21.0 & 21.8 & 19.7 & 21.0 & 22.8 & 26.1 & 17.9 & 23.4 \\
\hline C16:1 & 3.5 & 5.6 & 3.6 & 5.1 & 6.0 & 4.7 & 3.8 & 5.7 \\
\hline C18:0 & 4.5 & 5.9 & 7.9 & 6.9 & 6.0 & 8.1 & 4.8 & 6.6 \\
\hline C18:1n-9 & 10.8 & 15.1 & 12.9 & 13.9 & 9.6 & 17.1 & 16.9 & 27.2 \\
\hline C18:2n-6 & 2.1 & 2.2 & 2.4 & 1.5 & 3.3 & 2.1 & 1.7 & 3.1 \\
\hline C20:0 & 0.3 & 0.4 & 1.8 & 0.8 & 2.6 & 0.5 & 1.5 & 0.3 \\
\hline C20:1n-9 & 3.3 & 1.7 & 0.9 & 1.0 & 0.8 & 1.2 & 3.5 & 3.3 \\
\hline C18:3n-3 & 0.8 & 0.4 & 2.6 & 0.5 & 3.1 & 0.8 & 1.8 & 0.3 \\
\hline$C 20: 2 n-6$ & 2.6 & 2.0 & 1.4 & 1.5 & 1.4 & 1.2 & 1.3 & 0.6 \\
\hline C22:1n-9 & & 0.5 & & 0.9 & & 0.9 & 2.5 & 0.9 \\
\hline$C 20: 3 n-3$ & & & 1.6 & 0.7 & 2.0 & & 1.1 & \\
\hline$C 20: 4 n-6$ & 1.2 & 0.8 & 1.6 & 1.8 & 1.6 & 2.5 & 1.7 & 0.8 \\
\hline$C 22: 2 n-6$ & 0.6 & & 0.6 & 0.6 & 1.5 & & 0.8 & \\
\hline$C 20: 5 n-3$ & 12.4 & 16.4 & 9.4 & 11.1 & 13.0 & 6.2 & 14.1 & 7.9 \\
\hline$C 22: 3 n-3$ & 0.4 & 0.7 & 0.6 & 0.5 & & 0.3 & & \\
\hline$C 22: 5 n-3$ & 1.3 & 3.2 & 2.5 & 2.5 & 1.4 & 1.2 & 1.6 & 0.9 \\
\hline$C 22: 6 n-3$ & 25.2 & 17.5 & 22.5 & 20.9 & 15.3 & 20.4 & 20.1 & 9.3 \\
\hline n-3HUFA & 39.3 & 37.7 & 36.5 & 35.8 & 31.7 & 28.1 & 36.9 & 18.1 \\
\hline
\end{tabular}

$H M$ herring fish meal, $A M$ anchovy fish meal, $M M$ mackerel fish meal, $S M-A$ sardine fish meal-A, $S M-B$ sardine fish meal- $B, T M$ tuna meal, $P M-A$ pollock fish meal-A, $P M-B$ pollock fish meal-B

$21.4 \pm 2.10{ }^{\circ} \mathrm{C}$, and the photoperiod followed the natural conditions during the experimental period.

\section{Feces collection}

Triplicate groups of fish were hand-fed with one of the experimental diets to apparent satiation once a day at $15.00 \mathrm{~h}$. Two hours after feeding, the rearing tanks and collection column were brushed out in order to remove uneaten feed and fecal residues. The next day, feces were collected from the fecal collection columns at 9:00 h. Feces collected from the settling columns were immediately filtered with filter paper (Whatman \# 1) for $60 \mathrm{~min}$ at $4{ }^{\circ} \mathrm{C}$ and stored at $-75^{\circ} \mathrm{C}$ for chemical analyses. Fecal samples from each tank were pooled at the end of the experiment.

\section{Analytical methods}

Freeze-dried feed and feces samples were finely grounded using a grinder. Fish scales were removed from the feces samples using a $300-\mu \mathrm{m}$ sieve before analysis. Crude protein content was determined by the Kjeldahl method using an Auto Kjeldahl System (Buchi, Flawil, Switzerland). Crude lipid was determined by the ether-extraction method. Crude fiber was determined
Table 3 Formulation and chemical composition of the experimental diets

\begin{tabular}{|c|c|c|c|c|c|c|c|c|}
\hline & \multicolumn{8}{|c|}{ Diets } \\
\hline & $\mathrm{HM}$ & AM & MM & SM-A & SM-B & TM & PM-A & PM-B \\
\hline \multicolumn{9}{|l|}{ Ingredients (\%) } \\
\hline Herring fish meal & 72 & & & & & & & \\
\hline Anchovy fish meal & & 72 & & & & & & \\
\hline Mackerel fish meal & & & 72 & & & & & \\
\hline $\begin{array}{l}\text { Sardine fish } \\
\text { meal-A }\end{array}$ & & & & 72 & & & & \\
\hline $\begin{array}{l}\text { Sardine fish } \\
\text { meal-B }\end{array}$ & & & & & 72 & & & \\
\hline Tuna meal & & & & & & 72 & & \\
\hline $\begin{array}{l}\text { Pollock fish } \\
\text { meal-A }\end{array}$ & & & & & & & 72 & \\
\hline $\begin{array}{l}\text { Pollock fish } \\
\text { meal-B }\end{array}$ & & & & & & & & 72 \\
\hline Wheat flour & 14 & 14 & 14 & 14 & 14 & 14 & 14 & 14 \\
\hline a-potato-starch & 5 & 5 & 5 & 5 & 5 & 5 & 5 & 5 \\
\hline Wheat gluten & 2 & 2 & 2 & 2 & 2 & 2 & 2 & 2 \\
\hline Fish oil & 3.7 & 3.7 & 3.7 & 3.7 & 3.7 & 3.7 & 3.7 & 3.7 \\
\hline Vitamin premix ${ }^{a}$ & 1 & 1 & 1 & 1 & 1 & 1 & 1 & 1 \\
\hline Mineral premix ${ }^{b}$ & 1 & 1 & 1 & 1 & 1 & 1 & 1 & 1 \\
\hline Stay-C (50 \%) & 0.3 & 0.3 & 0.3 & 0.3 & 0.3 & 0.3 & 0.3 & 0.3 \\
\hline Vitamin E (25 \%) & 0.2 & 0.2 & 0.2 & 0.2 & 0.2 & 0.2 & 0.2 & 0.2 \\
\hline Choline salt (50 \%) & 0.3 & 0.3 & 0.3 & 0.3 & 0.3 & 0.3 & 0.3 & 0.3 \\
\hline $\mathrm{Cr}_{2} \mathrm{O}_{3}$ & 0.5 & 0.5 & 0.5 & 0.5 & 0.5 & 0.5 & 0.5 & 0.5 \\
\hline
\end{tabular}

Nutrient content

(dry matter basis)

$\begin{array}{lllllllll}\text { Crude protein (\%) } & 53.4 & 51.7 & 54.9 & 52.9 & 51.8 & 47.6 & 54.0 & 47.5 \\ \text { Crude lipid (\%) } & 9.3 & 8.5 & 7.8 & 9.6 & 8.6 & 9.7 & 8.0 & 7.5 \\ \text { Ash (\%) } & 12.6 & 16.0 & 13.1 & 13.4 & 12.8 & 16.4 & 12.3 & 20.2 \\ \text { NFE (\%) } & 24.7 & 23.8 & 24.2 & 24.1 & 26.8 & 26.3 & 25.7 & 26.6\end{array}$

${ }^{2}$ Vitamin premix contained the following ingredients ( $\mathrm{g} / \mathrm{kg}$ premix), which were diluted in cellulose: thiamin hydrochloride, 2.7; riboflavin, 9.1; pyridoxine hydrochloride, 1.8; niacin, 36.4; Ca-D-pantothenate, 12.7; myo-inositol, 181.8; D-biotin, 0.27 ; folic acid, 0.68; $p$-aminobenzoic acid, 18.2; menadione, 1.8; retinyl acetate, 0.73 ; cholecalciferol, 0.003 ; and cyanocobalamin, 0.003 ${ }^{\mathrm{b}}$ Mineral premix contained the following ingredients $(\mathrm{g} / \mathrm{kg}$ premix): $\mathrm{MgSO}_{4} \cdot 7 \mathrm{H}_{2} \mathrm{O}, 80.0 ; \mathrm{NaH}_{2} \mathrm{PO}_{4} \cdot 2 \mathrm{H}_{2} \mathrm{O}, 370.0 ; \mathrm{KCl}, 130.0$; ferric citrate, 40.0; $\mathrm{ZnSO}_{4} \cdot 7 \mathrm{H}_{2} \mathrm{O}, 20.0 ;$ Ca-lactate, 356.5; $\mathrm{CuCl}, 0.2 ; \mathrm{AlCl}_{3} \cdot 6 \mathrm{H}_{2} \mathrm{O}, 0.15 ; \mathrm{Kl}, 0.15$; $\mathrm{Na}_{2} \mathrm{Se}_{2} \mathrm{O}_{3}, 0.01 ; \mathrm{MnSO}_{4} \cdot \mathrm{H}_{2} \mathrm{O}, 2.0$; and $\mathrm{CoCl}_{2} \cdot 6 \mathrm{H}_{2} \mathrm{O}, 1.0$

${ }^{\mathrm{c} C a l c u l a t e d}=100-$ (crude protein + crude lipid + ash)

using an automatic analyzer (Fibertec, Tecator, Sweden), while ash content was determined by treatment in a muffle furnace at $600{ }^{\circ} \mathrm{C}$ for $4 \mathrm{~h}$. Gross energy content was analyzed using an adiabatic bomb calorimeter (Parr, USA). For amino acid composition, samples were freezedried and then hydrolyzed with $6 \mathrm{~N} \mathrm{HCl}$ at $110{ }^{\circ} \mathrm{C}$ for $24 \mathrm{~h}$. Amino acid concentrations in the experimental diets and fecal samples were determined using an automatic analyzer (Hitachi Model 835-50, Japan) equipped with an ion exchange column (Hitachi Resin \# 
2619, $2.6 \times 150 \mathrm{~mm}$, Japan). Lipid for fatty acid analysis was extracted by a combination of chloroform and methanol $(2: 1, v / v)$ using the method of Folch et al. (1957). Fatty acid methyl esters were measured by transesterification with $14 \% \mathrm{BF}_{3}$ methanol (Sigma, St Louis, MO, USA). The particular fatty acid composition was identified using a gas chromatography (PerkinElmer, Clarus 600, GC, USA) that has a flame ionization detector, equipped with SPTM-2560 capillary column $(100 \mathrm{~m} \times 0.25 \mathrm{~mm}$ i.d., film thickness $0.20 \mathrm{~mm}$; Supelco, Bellefonte, PA, USA). Injector and detector temperatures were $260{ }^{\circ} \mathrm{C}$. The column temperature was programmed from 140 to $240{ }^{\circ} \mathrm{C}$ at a rate of $5{ }^{\circ} \mathrm{C} / \mathrm{min}$. Helium was utilized by the carrier gas. Fatty acid composition from the samples was identified by comparison with retention times of the known standard fatty acid methyl esters (PUFA 37 component FAME Mix Supelco). Chromic oxide was determined by a wet-acid digestion method (Furukawa and Tsukahara 1966).

Apparent dry matter digestibility coefficients were calculated as $100-\left(100 \times\left(\% \mathrm{Cr}_{2} \mathrm{O}_{3}\right.\right.$ in diet $/ \% \mathrm{Cr}_{2} \mathrm{O}_{3}$ in feces)).

Apparent digestibility coefficients of nutrients, energy, essential amino acids, and selected fatty acids were calculated as $100-(100 \times(\%$ feed marker/\% feces marker $) \times$ (\% nutrient, energy, amino acid, or fatty acid in feces/ $\%$ nutrient, energy, amino acid, or fatty acid in feed)).

\section{Statistical analysis}

All data were subjected to one-way analysis of variance, followed by Duncan's multiple range test (Duncan 1955) at a significance level of $P<0.05$. Linear correlations were determined between nutrient digestibility and contents of the test ingredients (fish meals). All data are presented as mean \pm SE (standard error) of three replicate groups. All statistical analyses were carried out using SPSS version 20.0 (SPSS Inc., Chicago, IL, USA).

\section{Results}

The apparent digestibility coefficients (ADCs) of dry matter, crude protein, crude lipid, and energy of the extruded floating pellet diets containing various fish meals for olive flounder are shown in Table 4. The ADCs of dry matter ranged from 69 to $87 \%$. Dry matter ADCs of the MM, SM-A, SM-B, and PM-A diets were higher than those of the TM and PM-B diets. The dry matter ADC of PM-B was the lowest among the experimental groups.

Protein ADCs of diets ranged from 87 to $95 \%$. Protein $\mathrm{ADCs}$ of the MM, SM-A, and PM-A diets were significantly higher than those of the AM, SM-B, TM, and PM-B diets while the lowest values were observed in fish fed the TM and PM-B diets. Lipid ADCs ranged from 83
Table 4 Apparent digestibility coefficients (\%) of dry matter, crude protein, crude lipid, and energy in olive flounder fed the diets containing various fish meals

\begin{tabular}{lllll}
\hline Diets & Dry matter & Crude protein & Crude lipid & Energy \\
\hline HM & $81.5 \pm 1.47^{\mathrm{bc}}$ & $93.2 \pm 0.31^{c d}$ & $90.5 \pm 1.24^{\mathrm{b}}$ & $90.7 \pm 0.65^{c}$ \\
AM & $80.7 \pm 1.71^{\mathrm{bc}}$ & $91.6 \pm 1.47^{\mathrm{bc}}$ & $94.6 \pm 0.71^{c d}$ & $90.3 \pm 0.24^{c}$ \\
MM & $83.6 \pm 0.74^{\mathrm{cd}}$ & $95.3 \pm 0.16^{\mathrm{d}}$ & $94.7 \pm 0.91^{c d}$ & $93.5 \pm 0.49^{\mathrm{d}}$ \\
SM-A & $84.4 \pm 0.51^{\mathrm{cd}}$ & $95.1 \pm 0.18^{\mathrm{d}}$ & $95.9 \pm 0.06^{\mathrm{d}}$ & $93.0 \pm 0.07^{\mathrm{d}}$ \\
SM-B & $83.5 \pm 0.06^{\mathrm{cd}}$ & $90.8 \pm 0.08^{\mathrm{b}}$ & $93.1 \pm 0.46^{\mathrm{bcd}}$ & $89.3 \pm 0.11^{\mathrm{c}}$ \\
TM & $77.5 \pm 1.04^{\mathrm{b}}$ & $87.2 \pm 0.70^{\mathrm{a}}$ & $92.4 \pm 1.59^{\mathrm{bc}}$ & $86.2 \pm 0.40^{\mathrm{b}}$ \\
PM-A & $87.0 \pm 0.45^{\mathrm{d}}$ & $95.4 \pm 0.20^{\mathrm{d}}$ & $93.6 \pm 1.24^{\mathrm{bcd}}$ & $93.9 \pm 0.39^{\mathrm{d}}$ \\
PM-B & $69.2 \pm 2.97^{\mathrm{a}}$ & $87.2 \pm 1.29^{\mathrm{a}}$ & $83.0 \pm 1.82^{\mathrm{a}}$ & $83.5 \pm 0.98^{\mathrm{a}}$ \\
\hline
\end{tabular}

Values (mean \pm SE of triplicate groups) in the same column with different superscripts are significantly different $(P<0.05)$

to $96 \%$. The lipid ADCs of the PM-B diet was significantly lower than those of the other diets, and the SM-A group showed the highest value. Energy ADCs ranged from 84 to $94 \%$. The energy ADCs of the MM, SM-A, and PM-A diets were significantly higher than those of the other groups while the PM-B diet showed the lowest value.

Essential amino acid ADCs of diets containing various fish meals for olive flounder are shown in Table 5. In general, essential amino acid availability reflected crude protein digestibility, with fish fed the MM, SM-A, and PM-A diets showing the highest values compared to the other experimental groups. Amino acid digestibility values, for most essential amino acids, in TM were the lowest for juvenile olive flounder among the fish meals tested. Fatty acid ADCs of diets containing various fish meals for olive flounder are shown in Table 6. Among all fish meals, the ADC of selected fatty acids in PM-B was significantly lower than that of fatty acids in other fish meals.

\section{Discussion}

Dry matter ADC of various protein feedstuffs offers an estimate of overall digestibility, and a low value generally indicates that a high level of indigestible material is present in the feedstuff ( $\mathrm{Li}$ et al. 2013). Thus, dry matter ADCs have been considered to provide a better estimate of the amount of indigestible material present in feedstuffs in comparison with digestibility coefficients for individual nutrients (Luo et al. 2008). In this study, the MM, SM-A, SM-B, and PM-A diets were equally well digested and had higher dry matter ADCs than the TM and PM-B diets. These differences can be explained by the differences in origin, quality, and chemical composition of ingredients used in the diet. We found that the dry matter digestibility was positively correlated $(r=0.95)$ with ash content of fish meals tested in the current study. 
Table 5 Apparent amino acid digestibility coefficients (\%) of diets containing various fish meals for olive flounder

\begin{tabular}{|c|c|c|c|c|c|c|c|c|}
\hline \multirow{2}{*}{$\begin{array}{l}\text { Essential } \\
\text { amino } \\
\text { acids }\end{array}$} & \multicolumn{8}{|l|}{ Diets } \\
\hline & $\mathrm{HM}$ & AM & MM & SM-A & SM-B & TM & PM-A & PM-B \\
\hline Arg & $94.3 \pm 0.39^{c d}$ & $93.1 \pm 1.46^{b c}$ & $98.1 \pm 0.03^{f}$ & $96.6 \pm 0.19^{e f}$ & $92.9 \pm 0.27^{b c}$ & $89.8 \pm 0.65^{a}$ & $96.1 \pm 0.14^{\text {de }}$ & $92.0 \pm 0.39^{b}$ \\
\hline His & $93.2 \pm 0.41^{b c}$ & $90.8 \pm 1.77^{\mathrm{a}}$ & $98.1 \pm 0.13^{e}$ & $96.1 \pm 0.06^{\text {de }}$ & $92.1 \pm 0.15^{\mathrm{ab}}$ & $90.3 \pm 0.62^{a}$ & $95.0 \pm 0.28^{\mathrm{cd}}$ & $89.8 \pm 0.75^{a}$ \\
\hline lle & $92.7 \pm 0.60^{\text {cd }}$ & $90.5 \pm 2.23^{b c}$ & $97.0 \pm 0.13^{e}$ & $94.9 \pm 0.10^{\text {de }}$ & $90.6 \pm 0.28^{b c}$ & $87.6 \pm 0.86^{a}$ & $94.8 \pm 0.32^{\text {de }}$ & $89.0 \pm 0.48^{\mathrm{ab}}$ \\
\hline Leu & $93.1 \pm 0.48^{\mathrm{cd}}$ & $91.3 \pm 2.04^{b c}$ & $97.3 \pm 0.11^{\mathrm{e}}$ & $95.3 \pm 0.14^{\text {de }}$ & $91.0 \pm 0.21^{b c}$ & $88.0 \pm 0.79^{a}$ & $95.0 \pm 0.19^{\mathrm{de}}$ & $89.3 \pm 0.43^{a b}$ \\
\hline Lys & $84.5 \pm 0.62^{\text {de }}$ & $92.3 \pm 2.08^{\mathrm{cd}}$ & $97.8 \pm 0.11^{f}$ & $96.4 \pm 0.04^{e f}$ & $91.3 \pm 0.12^{b c}$ & $88.6 \pm 0.93^{a}$ & $95.3 \pm 0.21^{e^{e f}}$ & $89.5 \pm 0.50^{\mathrm{ab}}$ \\
\hline Met + Cys & $96.1 \pm 0.26^{d}$ & $94.5 \pm 1.23^{c}$ & $98.5 \pm 0.02^{e}$ & $97.3 \pm 0.01^{\text {de }}$ & $94.0 \pm 0.11^{c}$ & $88.5 \pm 0.36^{a}$ & $97.1 \pm 0.09^{\mathrm{de}}$ & $91.1 \pm 0.37^{b}$ \\
\hline Phe + Tyr & $92.2 \pm 0.67^{b c}$ & $90.2 \pm 1.89^{\mathrm{ab}}$ & $96.9 \pm 0.10^{d}$ & $94.8 \pm 0.21^{d}$ & $90.2 \pm 0.22^{\mathrm{ab}}$ & $88.5 \pm 0.71^{a}$ & $94.6 \pm 0.35^{\mathrm{cd}}$ & $88.7 \pm 0.42^{\mathrm{a}}$ \\
\hline Thr & $92.0 \pm 0.42^{b}$ & $90.1 \pm 1.83^{b}$ & $96.7 \pm 0.12^{c}$ & $94.4 \pm 0.24^{c}$ & $90.1 \pm 0.12^{b}$ & $86.6 \pm 0.66^{a}$ & $94.7 \pm 0.34^{c}$ & $87.7 \pm 0.48^{a}$ \\
\hline Val & $89.9 \pm 0.36^{c}$ & $86.5 \pm 1.94^{b}$ & $95.7 \pm 0.16^{e}$ & $92.7 \pm 0.24^{d}$ & $88.6 \pm 0.20^{b c}$ & $83.9 \pm 0.81^{a}$ & $93.4 \pm 0.76^{\text {de }}$ & $86.3 \pm 0.51^{\mathrm{ab}}$ \\
\hline
\end{tabular}

Values (mean \pm SE of triplicate groups) in the same row with different superscripts are significantly different $(P<0.05)$

It has been suggested that a high level of ash generally affects digestibility of dry matter and results in high waste outputs and can also cause mineral imbalances. Therefore, the low dry matter digestibility of the TM and PM-B diets may be attributed to their high ash content (20.1 and $26.4 \%$, respectively). Kitagima and Fracalossi (2011) reported low dry matter digestibility for fish and shrimp offal meal with high ash contents. Similar results have also been observed in rainbow trout (Oncorhynchus mykiss) (Bureau et al. 1999) and hybrid tilapia (O. niloticus $\times$ Oreochromis aureus) (Zhou and Yue 2012).

The protein quality of the dietary ingredients is usually the leading factor affecting fish performance and protein digestibility and is the first measure of its availability for fish (Yu et al. 2013). The ADC of protein in this study revealed that the protein of HM, MM, SM-A, and PM-A must be highly digestible by olive flounder. This indicates that each of these fish meals can be utilized efficiently as protein sources for olive flounder. The ADC of protein for the SM-A diet (95\%) is higher than that previously reported for rainbow trout (Gaylord et al.
2008). The ADC of protein for the MM diet (95\%) is higher than that reported for juvenile Pacific white shrimp, Litopenaeus vannamei (Lemos et al. 2009). The $\mathrm{ADC}$ of protein for the HM diet (93\%) is similar to that reported for herring fish meal in the Atlantic cod, $G$. morhua (Tibbetts et al. 2006), and salmonids such as the Atlantic salmon, Salmo salar (Anderson et al. 1997); coho salmon, O. kisutch (Sugiura et al. 1998); and rainbow trout (Burel et al. 2000). The ADC of protein for the AM diet $(91 \%)$ is similar to that reported for anchovy fish meal in salmonid species (Anderson et al. 1995; Sugiura et al. 1998, 2000; Thiessen et al. 2004; Glencross et al. 2005). In the present study, the protein $\mathrm{ADCs}$ of the TM and PM-B diets were lower than those of the other ingredients tested. The ADC of protein appeared to have a positive relationship with dry matter of the test ingredients $(r=0.84)$. The differences in ADC of protein among fish meals can be attributed to their different nutrient compositions, raw materials, species, locations, seasons of catch, and processing conditions used to produce the meal (Luo et al. 2008; Lemos et al. 2009; Terrazas-Fierro et al. 2010).

Table 6 Apparent fatty acid digestibility coefficients (\%) of diets containing various fish meals for olive flounder

\begin{tabular}{|c|c|c|c|c|c|c|c|c|}
\hline \multirow{2}{*}{$\begin{array}{l}\text { Fatty } \\
\text { acids }\end{array}$} & \multicolumn{8}{|l|}{ Diets } \\
\hline & $\mathrm{HM}$ & $\mathrm{AM}$ & MM & SM-A & SM-B & TM & PM-A & PM-B \\
\hline C14:0 & $91.7 \pm 0.12^{b}$ & $94.9 \pm 0.12^{b c}$ & $96.1 \pm 0.16^{c}$ & $97.0 \pm 1.51^{c}$ & $93.0 \pm 0.47^{b c}$ & $92.9 \pm 0.59^{b c}$ & $93.2 \pm 0.47^{b c}$ & $80.6 \pm 3.12^{2}$ \\
\hline C16:0 & $90.0 \pm 0.13^{b c}$ & $92.2 \pm 0.34^{b c}$ & $94.6 \pm 0.17^{c}$ & $93.1 \pm 0.40^{c}$ & $89.4 \pm 0.71^{b c}$ & $87.4 \pm 0.77^{b}$ & $93.7 \pm 0.26^{c}$ & $69.7 \pm 4.70^{\circ}$ \\
\hline C18:0 & $86.8 \pm 0.27^{\mathrm{bcd}}$ & $90.7 \pm 0.66^{\text {de }}$ & $91.9 \pm 0.24^{\mathrm{de}}$ & $94.1 \pm 0.37^{e}$ & $84.3 \pm 1.02^{b c}$ & $83.7 \pm 0.82^{b}$ & $89.4 \pm 0.38^{\text {cde }}$ & $68.9 \pm 4.69^{\circ}$ \\
\hline C18:1n-9 & $92.5 \pm 0.62^{b}$ & $95.5 \pm 0.17^{b}$ & $95.8 \pm 0.31^{b}$ & $95.2 \pm 0.25^{b}$ & $93.8 \pm 0.32^{b}$ & $95.9 \pm 2.16^{b}$ & $95.2 \pm 0.21^{b}$ & $80.5 \pm 2.53^{\mathrm{a}}$ \\
\hline C18:2n-6 & $88.9 \pm 0.74^{b}$ & $96.6 \pm 0.27^{c}$ & $97.1 \pm 0.29^{c}$ & $96.9 \pm 0.22^{c}$ & $93.3 \pm 0.75^{b c}$ & $95.5 \pm 0.22^{b c}$ & $93.9 \pm 0.24^{b c}$ & $72.1 \pm 6.24^{\circ}$ \\
\hline$C 18: 3 n-3$ & $93.4 \pm 0.11^{c d}$ & $96.5 \pm 0.27^{c d}$ & $97.8 \pm 0.80^{d}$ & $96.4 \pm 0.27^{c d}$ & $90.1 \pm 0.40^{b c}$ & $85.8 \pm 0.60^{b}$ & $91.7 \pm 0.44^{\mathrm{bcd}}$ & $61.3 \pm 6.39^{\circ}$ \\
\hline$C 20: 4 n-6$ & $95.7 \pm 0.19^{c}$ & $97.4 \pm 0.18^{c}$ & $97.1 \pm 0.12^{c}$ & $94.3 \pm 0.43^{b c}$ & $92.7 \pm 1.87^{b c}$ & $94.4 \pm 0.63^{b c}$ & $89.9 \pm 3.15^{b}$ & $82.6 \pm 2.59^{\circ}$ \\
\hline$C 20: 5 n-3$ & $97.2 \pm 0.07^{b}$ & $98.5 \pm 0.08^{b}$ & $98.7 \pm 0.08^{b}$ & $97.3 \pm 0.48^{b}$ & $97.5 \pm 0.21^{b}$ & $98.2 \pm 0.34^{b}$ & $97.9 \pm 0.20^{b}$ & $92.5 \pm 1.52^{\circ}$ \\
\hline$C 22: 6 n-3$ & $96.7 \pm 0.05^{b}$ & $98.0 \pm 0.14^{b}$ & $98.0 \pm 0.36^{b}$ & $97.3 \pm 0.20^{b}$ & $96.8 \pm 0.14^{b}$ & $96.9 \pm 0.57^{b}$ & $97.4 \pm 0.10^{b}$ & $88.0 \pm 1.89^{\circ}$ \\
\hline
\end{tabular}

Values (mean \pm SE of triplicate groups) in the same row with different superscripts are significantly different $(P<0.05)$ 
The quality of dietary protein depends on its amino acid composition and their digestibility and availability (Rollin et al. 2003). Lack of an essential amino acid leads to poor dietary protein utilization and therefore reduces growth and deceases feed efficiency. Although the data presented in this study suggest a reasonable agreement between protein and amino acid digestibilities, individual amino acid availabilities within a feed ingredient are variable. The amino acid availability coefficients of the MM, SM-A, and PM-A diets were significantly higher than those of the other experimental diets, suggesting that olive flounder can efficiently utilize these fish meals. In most of the cases, ADCs of essential amino acid in the TM diet were the lowest of all the fish meals that were tested, possibly due to lower quality of the starting raw material. Many researchers have reported that some amino acids of fish meal are inefficiently utilized or made unavailable due to differences in the processing conditions or the low quality of the raw material processed (Wilson et al. 1981; Anderson et al. 1992, Anderson et al. 1995; Yamamoto et al. 1998; Mu et al. 2000, Chu et al. 2015).

The ADC of dietary lipid usually ranges from 85 to $95 \%$ in fish (NRC 1993). In the present study, lipid digestibilities were considered to be high ( $>90 \%$ ), except for PM-B (83\%). Previous studies reported ADC values of lipid in different fish meals including Peruvian fish meal (94 \%) for juvenile snakehead, $O$. argus (Yu et al. 2013); white fish meal (78 \%); and brown fish meal (76 \%) for loach, Misgurnus anguillicaudatus (Chu et al. 2015). The digestibility of lipids is known to be influenced by a number of factors, including degree of unsaturation, dietary lipid level, and various other constituents (Yuan et al. 2010).

Digestibility of fatty acids is identified to be influenced by a number of factors including their chain length, degree of unsaturation, level of incorporation in dietary fat, and other constituent fatty acids and their melting points (Olsen et al. 2000; Martins et al. 2009; Oujifard et al. 2012). High specificity towards unsaturated fatty acids has commonly been found for fish digestive lipases (Caballero et al. 2002). In the present study, all diets showed high fatty acid digestibility except for PM-B. The low digestibility coefficient of fatty acids for the PM-B diet may be attributed to the poor quality of raw material processed. However, digestibility of individual fatty acids has been affected by other factors including emulsification, enzymatic hydrolysis, and micellar incorporation (Francis et al. 2007).

The ADCs of energy for the HM and SM-A diets, in the current study, are in the same range as reported in Atlantic cod (93\%) (Tibbetts et al. 2006) and rainbow trout (95\%) (Gaylord et al. 2008). It has been reported that carnivorous fish are capable of efficiently utilizing energy from animal products (Sullivan and Reigh 1995; Gaylord and Gatlin 1996; McGoogan and Reigh 1996; Lee 2002; Zhou et al. 2004). It was found that a high ash content of fish meal might reduce energy digestibility (Gomes et al. 1995).

\section{Conclusions}

The MM, SM-A, and PM-A diets showed higher dry matter, crude protein, crude lipid, and energy ADCs than the other diets. Due to variation within individual amino acid and fatty acid ADCs among diets, the use of specific amino acid and fatty acid ADCs may allow more accurate and economical formulation of the feed for olive flounder.

\section{Abbreviations \\ ADCs, apparent digestibility coefficients; AM, anchovy fish meal; Arg, arginine; His, histidine; HM, herring fish meal; lle, isoleucine; Leu, leucine; Lys, lysine; Met + Cys, methionine + cysteine; MM, mackerel fish meal; Phe + Tyr, phenylalanine + tyrosine; PM-A, pollock fish meal-A; PM-B, pollock fish meal-B; SE, standard error; SM-A, sardine fish meal-A; SM-B, sardine fish meal-B; Thr, threonine; TM, tuna fish meal; Val, valine}

\section{Acknowledgements}

This work was supported by a grant from the National Institute of Fisheries Science (R2016016) in Korea.

\section{Funding}

This study was funded by a grant from the National Institute of Fisheries Science (R2016016) in Korea. The funding organization played an active role in the manufacture of the experimental feed and analyses.

\section{Availability of data and materials}

All datasets generated during and/or analyzed during the current study are available from the corresponding author on reasonable request.

\section{Authors' contributions}

MMR conducted the feeding trial and drafted the manuscript. HSH, KWK, $\mathrm{KDK}$, and BJL manufactured the experimental feed and performed the analyses. SML conceived and designed the study and experimental facility and also revised the manuscript. All authors read and approved the final manuscript.

\section{Competing interests}

The authors declare that they have no competing interests.

\section{Consent for publication}

Not applicable

Ethics approval and consent to participate

Experimental protocols followed the guidelines of the Animal Care and Use Committee of Gangneung-Wonju National University.

\section{Author details}

${ }^{1}$ Department of Marine Biotechnology, Gangneung-Wonju National University, Gangneung 25457, South Korea. ${ }^{2}$ Aquafeed Research Center, National Institute of Fisheries Science, Pohang 37517, South Korea.

Received: 4 March 2016 Accepted: 18 July 2016

Published online: 02 August 2016

\section{References}

Allan GL, Booth MA. Effects of extrusion processing on digestibility of peas, lupins, canola meal and soybean meal in silver perch Bidyanus bidyanus (Mitchell) diets. Aquac Res. 2004;35:981-91. 
Allan GL, Parkinson S, Booth MA, Stone DAJ, Rowland SJ, Frances J, Warner-Smith R. Replacement of fish meal in diets for Australian silver perch, Bidyanus bidyanus: I. Digestibility of alternative ingredients. Aquaculture. 2000;186:293-310.

Anderson JS, Lall SP, Anderson DM, Chandrasoma J. Apparent and true availability of amino acids from common feed ingredients for Atlantic salmon (Salmo salar) reared in sea water. Aquaculture. 1992;108:111-24.

Anderson JS, Lall SP, Anderson DM, McNiven MA. Availability of amino acids from various fish meals fed to Atlantic salmon (Salmo salar). Aquaculture. 1995;138:291-301.

Anderson JS, Higgs DA, Beames RM, Rowshandeli M. Fish meal quality assessment for Atlantic salmon (Salmo salar L.) reared in sea water. Aquac Nutr. 1997:3:25-38.

Barrows FT, Hardy RW. Feed manufacturing technology. In: Stickney RR, editor. Encyclopedia of aquaculture. New York: Wiley; 2000. p. 354-9.

Bureau DP, Harris AM, Cho CY. Apparent digestibility of rendered animal protein ingredients for rainbow trout (Oncorhynchus mykiss). Aquaculture. 1999;180:345-58.

Burel C, Boujard T, Tulli F, Kaushik SJ. Digestibility of extruded peas, extruded lupin and rapeseed meal in rainbow trout (Oncorhynchus mykiss) and turbot (Psetta maxima). Aquaculture. 2000;188:285-98.

Caballero MJ, Obach A, Rosenlund G, Montero D, Gisvold M, Izquierdo MS. Impact of different dietary lipid sources on growth, lipid digestibility, tissue fatty acid composition and histology of rainbow trout, Oncorhynchus mykiss. Aquaculture. 2002;214:253-71.

Cho SH, Lee SM, Park BH, Lee SM. Effect of feeding ratio on growth and body composition of juvenile olive flounder Paralichthys olivaceus fed extruded pellets during the summer season. Aquaculture. 2006;251:78-84.

Chu ZJ, Yu DH, Yuan YC, Qiao Y, Cai WJ, Shu H, Lin YC. Apparent digestibility of selected protein feed ingredients for loach Misgurnus anguillicaudatus. Aquac Nutr. 2015;21:425-32.

Deng J, Mai K, Ai Q, Zhang W, Tan B, Xu W, Liufu Z. Alternative protein sources in diets for Japanese flounder Paralichthys olivaceus (Temminck and Schlegel): II. Effects on nutrient digestibility and digestive enzyme activity. Aquac Res. 2010;41:861-70.

Duncan DB. Multiple-range and multiple F-tests. Biometrics. 1955;11:1-42.

Folch J, Lees M, Sloane-Stanley GH. A simple method for the isolation and purification of total lipids from animal tissues. J Biol Chem. 1957;226:497-509.

Francis DS, Turchini GM, Jones PL, De Silva SS. Effects of fish oil substitution with a mix blend vegetable oil on nutrient digestibility in Murray cod, Maccullochella peelii peelii. Aquaculture. 2007;269:447-55.

Furukawa A, Tsukahara $\mathrm{H}$. On the acid digestion for the determination of chromic oxide as an index substance in the study of digestibility of fish feed. Bull Jpn Soc Sci Fish. 1966;32:502-6.

Gaylord TG, Gatlin III DM. Determination of digestibility coefficients of various feedstuffs for red drum (Sciaenops ocellatus). Aquaculture. 1996;139:303-14.

Gaylord TG, Barrows FT, Rawles SD. Apparent digestibility of gross nutrients from feedstuffs in extruded feeds for rainbow trout, Oncorhynchus mykiss. J Word Aquac Soc. 2008;39:827-34.

Glencross B, Evans D, Dods K, McCafferty P, Hawkins W, Maas R, Sipsas S. Evaluation of the digestible value of lupin and soybean protein concentrates and isolates when fed to rainbow trout, Oncorhynchus mykiss, using either stripping or settlement faecal collection methods. Aquaculture. 2005;245:211-20.

Glencross BD, Booth M, Allan GL. A feed is only as good as its ingredients-a review of ingredient evaluation strategies for aquaculture feeds. Aquac Nutr. 2007;13:17-34.

Gomes EF, Rema P, Kaushik SJ. Replacement of fish meal by plant proteins in the diet of rainbow trout (Oncorhynchus mykiss): digestibility and growth performance. Aquaculture. 1995;130:177-86.

Hardy RW. Utilization of plant proteins in fish diets: effects of global demand and supplies of fishmeal. Aquac Res. 2010;41:770-6.

Kim KD, Kim DG, Kim SK, Kim KW, Son MH, Lee SM. Apparent digestibility coefficients of various feed ingredients for olive flounder, Paralichthys olivaceus. Kor J Fish Aquat Sci. 2010;43:325-30.

Kim KW, Kim SS, Khosravi S, Rahimnejad S, Lee KJ. Evaluation of Sargassum fusiforme and Ecklonia cava as dietary additives for olive flounder (Paralichthys olivaceus). Turk J Fish Aquat Sci. 2014;14:321-30.

Kitagima RE, Fracalossi DM. Digestibility of alternative protein-rich feedstuffs for channel catfish, Ictalurus punctatus. J World Aquac Soc. 2011;42:306-12.

Köprücü K, Özdemir Y. Apparent digestibility of selected feed ingredients for Nile tilapia (Oreochromis niloticus). Aquaculture. 2005;250:308-16.
Lee SM. Apparent digestibility coefficients of various feed ingredients for juvenile and grower rockfish (Sebastes schlegeli). Aquaculture. 2002;207:79-95.

Lemos D, Lawrence AL, Siccardi AJ. Prediction of apparent protein digestibility of ingredients and diets by in vitro $\mathrm{pH}$ stat degree of protein hydrolysis with species-specific enzymes for juvenile Pacific white shrimp Litopenaeus vannamei. Aquaculture. 2009;295:89-98.

Li MH, Oberle DF, Lucas PM. Apparent digestibility of alternative plant-protein feedstuffs for channel catfish, Ictalurus punctatus (Rafinesque). Aquac Res. 2013:44:282-8.

Liu H, Wu X, Zhao W, Xue M, Guo L, Zheng Y, Yu Y. Nutrients apparent digestibility coefficients of selected protein sources for juvenile Siberian sturgeon (Acipenser baerii Brandt), compared by two chromic oxide analyses methods. Aquac Nutr. 2009;15:650-6.

Luo Z, Tan XY, Chen YD, Wang WM, Zhou G. Apparent digestibility coefficients of selected feed ingredients for Chinese mitten crab Eriocheir sinensis. Aquaculture. 2008;285:141-5.

Luo Z, Li XD, Gong SY, Xi WQ. Apparent digestibility coefficients of four feed ingredients for Synechogobius hasta. Aquac Res. 2009;40:558-65.

Martins DA, Valente LMP, Lall SP. Apparent digestibility of lipid and fatty acids in fish oil, poultry fat and vegetable oil diets by Atlantic halibut, Hippoglossus hippoglossus L. Aquaculture. 2009;294:132-7.

McGoogan BB, Reigh RC. Apparent digestibility of selected ingredients in red drum (Sciaenops ocellatus) diets. Aquaculture. 1996;141:233-44.

Mu YY, Lam TJ, Guo JY, Shim KF. Protein digestibility and amino acid availability of several protein sources for juvenile Chinese hairy crab Eriocheir sinensis $\mathrm{H}$. Milne-Edwards (Decapoda, Grapsidae). Aquac Res. 2000;31:757-65.

NRC (National Research Council). Nutrient requirements of fish. Washington, DC: National Academy Press; 1993. 114 pp.

Olsen RE, Myklebust R, Ring $\varnothing$, Mayhew TM. The influences of dietary linseed oil and saturated fatty acids on caecal enterocytes in Arctic char (Salvelinus alpinus L.): a quantitative ultrastructural study. Fish Physiol Biochem. 2000;22:207-16.

Oujifard A, Seyfabadi J, Kenari AA, Rezaei M. Growth and apparent digestibility of nutrients, fatty acids and amino acids in Pacific white shrimp, Litopenaeus vannamei, fed diets with rice protein concentrate as total and partial replacement of fish meal. Aquaculture. 2012;342-343:56-61.

Rollin X, Mambrini M, Abboudi T, Larondelle Y, Kaushik SJ. The optimum dietary indispensable amino acid pattern for growing Atlantic salmon (Salmo salar L.) fry. Brit J Nutr. 2003;90:865-76.

Sugiura SH, Dong FM, Rathbone CK, Hardy RW. Apparent protein digestibility and mineral availabilities in various feed ingredients for salmonid feeds. Aquaculture. 1998;159:177-202.

Sugiura SH, Babbitt JK, Dong FM, Hardy RW. Utilization of fish and animal byproduct meals in low-pollution feeds for rainbow trout Oncorhynchus mykiss (Walbaum). Aquac Res. 2000;31:585-93.

Sullivan JA, Reigh RC. Apparent digestibility of selected feedstuffs in diets for hybrid striped bass (Morone saxatilis $+\times$ Morone chrysops $\hat{\jmath})$. Aquaculture. 1995;138:313-22.

Terrazas-Fierro M, Civera-Cerecedo R, Ibarra-Martínez L, Goytortúa-Bores E, Herrera-Andrade M, Reyes-Becerra A. Apparent digestibility of dry matter, protein, and essential amino acid in marine feedstuffs for juvenile whiteleg shrimp Litopenaeus vannamei. Aquaculture. 2010:308:166-73.

Thiessen DL, Maenz DD, Newkirk RW, Classen HL, Drew MD. Replacement of fishmeal by canola protein concentrate in diets fed to rainbow trout (Oncorhynchus mykiss). Aquac Nutr. 2004;10:379-88.

Tibbetts SM, Lall SP, Milley JE. Apparent digestibility of common feed ingredients by juvenile haddock, Melanogrammus aeglefinus L. Aquac Res. 2004:35:643-51.

Tibbetts SM, Milley JE, Lall SP. Apparent protein and energy digestibility of common and alternative feed ingredients by Atlantic cod, Gadus morhua (Linnaeus, 1758). Aquaculture. 2006:261:1314-27.

Udo IU, Ekanem SB, Ndome CB. Determination of optimum inclusion level of some plant and animal protein-rich feed ingredients in least-cost ration for African catfish (Clarias gariepinus) fingerlings using linear programming technique. Int J Oceanogra Marine Ecol Sys. 2012;1:24-35.

Wilson RP, Robinson EH, Poe WE. Apparent and true availability of amino acids from common feed ingredients for channel catfish. J Nutr. 1981;111:923-9.

Yamamoto T, Akimoto A, Kishi S, Unuma T, Akiyama T. Apparent and true availabilities of amino acids from several protein sources for fingerling rainbow trout, common carp, and red sea bream. Fish Sci. 1998;64:448-58. 
Yisa AG, Edache JA, Udokainyang AD, lloama CN. Growth performance and carcass yield of broiler finishers fed diets having partially or wholly withdrawn fish meal. Int J Poultry Sci. 2013;12:117-20.

Yu HR, Zhang Q, Cao H, Wang XZ, Huang GQ, Zhang BR, Fan JJ, Liu SW, Li WZ, Cui Y. Apparent digestibility coefficients of selected feed ingredients for juvenile snakehead, Ophiocephalus argus. Aquac Nutr. 2013;19:139-47.

Yuan YC, Gong SY, Yang HJ, Lin YC, Yu DH, Luo Z. Apparent digestibility of selected feed ingredients for Chinese sucker, Myxocyprinus asiaticus. Aquaculture. 2010;306:238-43.

Zhou QC, Yue YR. Apparent digestibility coefficients of selected feed ingredients for juvenile hybrid tilapia, Oreochromis niloticus $\times$ Oreochromis aureus. Aquac Res. 2012;43:806-14.

Zhou QC, Tan BP, Mai KS, Liu YJ. Apparent digestibility of selected feed ingredients for juvenile cobia (Rachycentron canadum). Aquaculture. 2004;241:441-51

Submit your next manuscript to BioMed Central and we will help you at every step:

- We accept pre-submission inquiries

- Our selector tool helps you to find the most relevant journal

- We provide round the clock customer support

- Convenient online submission

- Thorough peer review

- Inclusion in PubMed and all major indexing services

- Maximum visibility for your research

Submit your manuscript at www.biomedcentral.com/submit 